\title{
一般口演 20
}

\author{
咀嚼は胃の活動を一過性に抑制しその後増大させる \\ Mastication evokes transient suppression and subsequent enhancement of gastric activity \\ ○高田寛子，大牟禮治人，宮脇正一 \\ Hiroko Takada, Haruhito Ohmure, Shouichi Miyawaki \\ 鹿児島大学大学院医歯学総合研究科歯科矯正学分野 \\ Department of Orthodontics, Kagoshima University Graduate School of Medical and Dental Sciences
}

\section{I. 目的}

咀嚼は消化管機能と密接に関連すると考えられてい る。しかし，咀嚼が胃排出能に及ぼす影響を調べた過去 の報告では，咀嚼が胃排出を促進させるとする報告 ${ }^{1)}$ と 変化しないとする報告 ${ }^{2)}$ があるなど両者の関連について は不明な点が多い。

今回，我々は消化管機能に影響を及ぼす咀嚼と関連す る食物の粉砕度, 味覚, 嗅覚などの要因を制御すること で，咀嚼と胃の活動の関連について新たな知見を得たの で報告する。

\section{II. 方 法}

\section{1. 対 象}

第三大臼歯以外に喪失歯がない個性正常咬合を呈する 健康な成人男性 14 名（平均年齢 $24.2 \pm 5.3$ 歳）で，顎口 腔機能異常や上部消化器疾患の既往のあるものは対象か ら除外した。

\section{2. データ計測}

\section{1) 胃排出能の計測}

胃排出能の計測には ${ }^{13} \mathrm{C}$ 呼気試験を用いた ${ }^{3)}$. 食物粉 砕度の影響を除外するため, 試験食には液状食（ラコー ル, 大塚製薬， $200 \mathrm{kcal} / 200 \mathrm{ml}$ ) を使用し，標識には $13 \mathrm{C}$ 酢酸ナトリウム $100 \mathrm{mg}$ を使用した。呼気採取は試 験食摂取前と摂取後 $1,5,10,15,20,25,30,40$, 50, 60, 75, 90, 105, 135, 150, 165，180，210，240 分の計 20 回行った. 採取した呼気を赤外分光分析装置 で分析し, 通法に従って Tmax, $\mathrm{T}_{1 / 2}$, Tlag, GEC を求
めた ${ }^{3)}$ 。また, Wagner-Nerson 法を用いて ${ }^{13} \mathrm{CO}_{2}$ 呼気排 出速度から試験食の胃排出速度を求めた ${ }^{4)}$.

2 ）胃運動機能の計測

過去の報告に従い，4個のディスポーサブル電極を腹 部に貼付し，携帯型胃電図計（NiproEG，二プロ）を用 いて胃電図を記録した ${ }^{5)}$ ・データはスペクトル解析を行 い（EGS2，グラム株式会社)，ピーク周波数とドミナン トパワーを求めた。

3 ) 自律神経機能の計測

多用途生体アンプ (Polymate II, TEAC) で記録した CM5 誘導心電図からで R-R 間隔変動の high frequency power (HFP) と low frequency power (LFP) を求め (Map1060, 日本サンテク), HFP を副交感神経活動の 指標, HFP と LFP の比率 ( LFP/HFP) を交感神経活 動の指標として用いた。

\section{3. 実験手順}

咀嚼あり（MST）となし (CNT) の 2 条件下でデー タの計測を行った。試験の順序はランダムに決定し，試 験と試験の間は最低 3 日以上空けた。被験者には試験前 日夜 9 時以降の絶飲食を指示し, 計測は朝 8 時から開始 した。体動や体位の影響を排除するため計測は左側臥位 で行った。試験食は 1 分間隔で 4 回に分けて摂取させ, MST では摂取中に無味無臭のガムベースを計 5 分間咀 嚼させた（図 1 ).

\section{4. 統計解析}

2 群間の差の有意性の検定にはデータの分布に応じ て， $\mathrm{t}$ 検定もしくはウィルコクソン検定を用いた. 


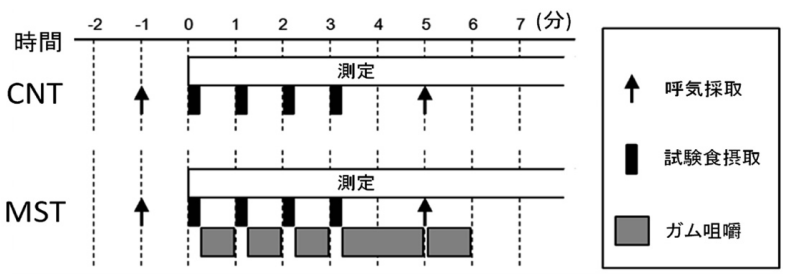

図 1 実験手順

\section{III. 結果及び考察}

${ }^{13} \mathrm{C}$ 呼気試験の結果，MST 群では Tmax, Tlag, $\mathrm{T}_{1 / 2}$ が有意に遅延し，GECが有意に低下していた（表 1 , 図 2 A). Wagner-Nerson 法で胃排出速度を算出したと ころ, MST 群は試験食摂取後 $0 \sim 20$ 分に打ける胃排出 が有意に低下し, 排出曲線は CNT 群と比べ右下方に偏 位していた（図 2 B）.

胃電図のドミナントパワーは, CNT 群では試験食摂 取後すぐに上昇したのに対して, MST 群では試験食摂 取後 $0 \sim 10$ 分で一過性の抑制認められ，その後，持続 的な増大が認められた (図 $3 \mathrm{~A}$ ). 胃電図のドミナント 周波数に 2 群間で有意な差は認められなかった（図 3 B).

R-R 間隔変動の HFP は, MST 群では試験食摂取後 0 〜 後において有意に低下していた。 LFP/HFPは，2 群間で有意な差は認められなかった。

以上の結果から，咀嚼によって胃活動の一過性の抑制 が起こり, その結果, 胃から十二指腸への食物排出が一 時的に抑制されることが分かった。また，この抑制は一 過性であり，抑制後には胃活動は持続的に六進すること もわかった。咀嚼中は副交感神経活動が一過性に低下し ていたことから, これらの変化には自律神経活動が関与 していることが示唆される。

\section{N. 文献}

1) Pera P, Bucca C, Borro R, et al. Influence of mastication on gastric emptying. J Dent Res 2002; 81(3): 179-181.

2) Poitras P, Boivin M, Morais J, et al. Gastric emptying of solid food in edentulous Patients. Digestion 1995; 56(6): 483-487.

3 ) Ghoos YF, Maes BD, Geypens BJ, et al. Measurement of gastric emptying rate of solids by means of a carbon-labeled octanoic acid breath test.

\begin{tabular}{lcccc} 
& 表 1 & \multicolumn{2}{c}{ 胃排出能に関連する指標の比較 } \\
& $\begin{array}{c}\text { CNT } \\
\text { Mean (SD) }\end{array}$ & $\begin{array}{c}\text { MST } \\
\text { Mean (SD) }\end{array}$ & $\begin{array}{c}\text { Difference } \\
\text { Mean }(95 \% \text { Cl) }\end{array}$ & Pvalue \\
\hline$T_{\max }$ (分) & $66.6(12.7)$ & $81.3(13.7)$ & $14.7(8.1-21.2)$ & 0.002 \\
$\mathrm{~T}_{1 / 2}$ (分) & $123.8(18.4)$ & $136.6(21.9)$ & $12.8(6.0-19.6)$ & 0.001 \\
$\mathrm{~T}_{\text {lag }}$ (分) & $24.1(4.9)$ & $30.6(5.6)$ & $6.5(3.5-9.4)$ & $<0.001$ \\
GEC & $3.30(0.27)$ & $3.20(0.28)$ & $-0.10(-0.18-0.01)$ & 0.028 \\
\hline
\end{tabular}

$\mathrm{Cl}$, condence interval; GEC, gastric emptying coefficient

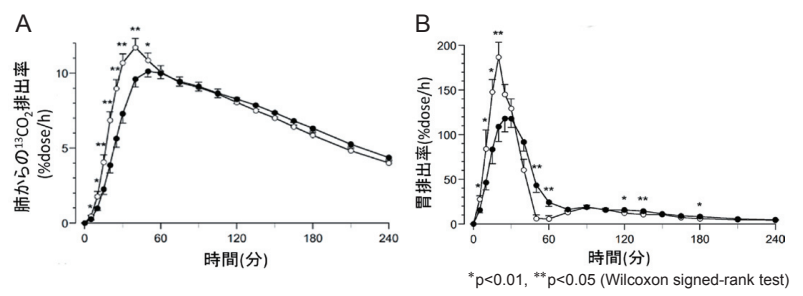

図2 ${ }^{13} \mathrm{C}$ 呼気試験の結果
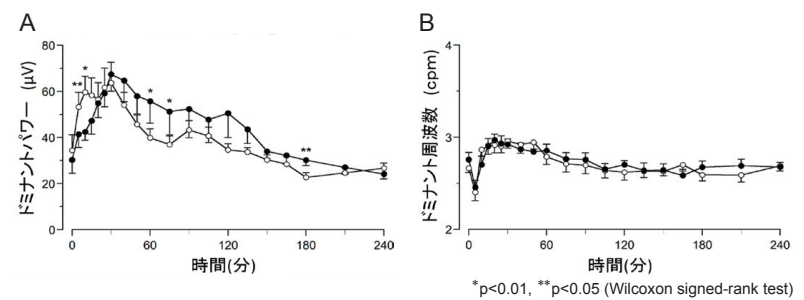

図 3 胃電図の解析結果

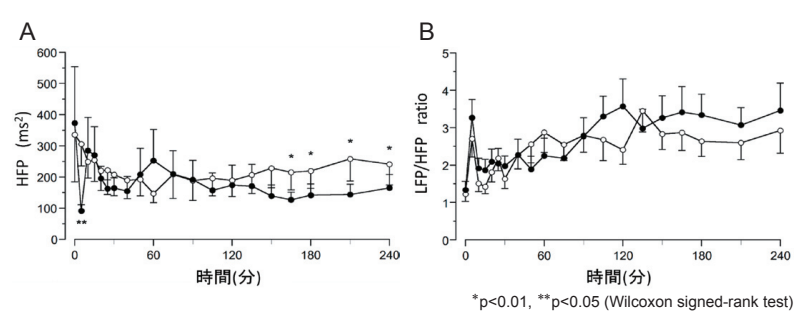

図 4 自律神経機能解析の結果

Gastroenterology 1993; 104(6): 1640-1647.

4 ) Sanaka M, Nakada K, Nosaka C,et al. The WagnerNelsonvmethod makes the [13C]-breath test comparable to radioscintigraphy in measuring gastric emptying of a solid/liquid mixed meal in humans. Clin Exp Pharmacol Physiol 2007; 34(7): 641-644.

5 ) Kato M, Sakai T, Yabe K,et al. Gastric myoelectrical activity increases after moderate-intensity exercise with no meals under suppressed vagal nerve activity. Jpn J Physiol 2004; 54(3): 221-228. 